\title{
Political Economy Determinants of Non-agricultural Trade Policy
}

\author{
Subhayu Bandyopadhyay and Suryadipta Roy
}

\begin{abstract}
The authors investigate several existing political economy hypotheses on trade policy using crosscountry trade-protection data for non-agricultural goods. The authors find that a left-leaning political regime leads to pro-labor trade policies only for a subset of trade policy measures. In addition, they find that income inequality and country-level corruption appear to be important determinants of trade policy. For various measures of trade protection, it appears that corruption tends to hurt labor interests by increasing trade protection in labor-abundant countries and reducing trade protection in capital-abundant countries. This finding suggests that corruption, among other factors, may move trade policy away from the desires of the median voter. (JEL F10, F11, F13, D73)
\end{abstract}

Federal Reserve Bank of St. Louis Review, March/April 2011, 93(2), pp. 89-104.

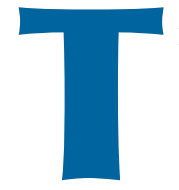

rade policy is often used by policymakers to favor certain constituencies. Tariffs and non-tariff barriers lead to increases in the price of the goods produced by import-competing sectors. Consequently, incomes of some factors of production in these sectors often rise at the expense of other factors. The theoretical foundations of this idea come from the famous Stolper-Samuelson theorem, which shows that protection raises the real return of the factor used intensively by the importcompeting sector, while reducing the real return of the factor used intensively by the export sector. This result along with the Heckscher-Ohlin theorem on trade patterns suggest that, for a given country, greater protectionism causes hardships for its abundant factor but benefits its scarce factor. Thus, protectionism causes labor to lose in labor-abundant countries but gain in capitalabundant countries.

Consequently, if capital ownership is concentrated in the hands of a few in both labor- and capital-abundant countries, then the median voter in both countries will be a laborer. Majority voting will favor trade liberalization (or free trade) in labor-abundant countries but protectionism in capital-abundant ones (where labor loses from trade). The greater the income inequality in a country, the more pronounced this effect is likely to be. Therefore, one can expect inequality to reduce trade protection in labor-abundant countries, while raising it in capital-abundant ones.

The motive for appeasing the majority may be reinforced or neutralized by the political ideology of the government. For example, an increase in the leftist orientation of a government may lead to an increase in the weight attached to labor welfare relative to capital welfare in the government's weighted objective function. This will result in trade policies that are more pro-labor and complementary to the median-voter effect discussed above.

Dutt and Mitra (2002, 2005) provide evidence in support of both the inequality and political ideology hypotheses, respectively. Using a framework similar to the Heckscher-Ohlin Stolper-

Subhayu Bandyopadhyay is a research officer and economist at the Federal Reserve Bank of St. Louis. Suryadipta Roy is an assistant professor of economics at High Point University.

(C) 2011, The Federal Reserve Bank of St. Louis. The views expressed in this article are those of the author(s) and do not necessarily reflect the views of the Federal Reserve System, the Board of Governors, or the regional Federal Reserve Banks. Articles may be reprinted, reproduced, published, distributed, displayed, and transmitted in their entirety if copyright notice, author name(s), and full citation are included. Abstracts, synopses, and other derivative works may be made only with prior written permission of the Federal Reserve Bank of St. Louis. 
Samuelson framework, Djerdijan (2007) studies the simultaneous interaction of inequality and political ideology on trade policy. He finds that an increase in income inequality in a pro-worker regime is associated with more equitable trade policies, while in a pro-capitalist regime it is associated with more inequitable trade policies.

Our paper adds to the existing literature in the following ways. First, unlike the existing literature on cross-country trade policy, we use tradeprotection data for the non-agricultural sector instead of aggregate trade data. We do this because, while the non-agricultural sector (e.g., mining and manufacturing) can be categorized as either labor intensive or capital intensive, it is difficult to ignore land as a third factor of production for the agricultural sector. Therefore, given that a prime motivation of this study is to understand how trade policy affects income distribution between labor and capital, using non-agricultural trade-protection data is more appropriate than using aggregate trade data. Second, in addition to studying the inequality and political ideology hypotheses, we incorporate a corruption hypothesis as another determinant of trade policy. The theoretical motivation behind incorporating corruption involves political influence: According to interest group models of international trade (Findlay and Wellisz, 1982; Hillman, 1982; and Grossman and Helpman, 1994), organized special interest groups lobby the government for trade protection and also provide campaign contributions to influence policy. Recent work by Gawande, Krishna, and Olarreaga (2009) suggests that the weights that governments attach to these contributions are positively correlated with levels of corruption. That is, more-corrupt governments attach higher weights to campaign contributions (relative to social welfare) in their respective objective functions. We build on this strand of the literature by allowing the level of corruption to interact with the capital-to-labor ratio. This allows us to analyze how corruption is associated with factor abundance in a Heckscher-Ohlin type model. The existing literature on the effects of corruption on trade openness and income distribution is relatively sparse. In a recent contribution, Roy (2010) finds corruption to be anti-labor:
For the countries he studied, it reduces trade openness (measured by the trade-to-GDP [gross domestic product] ratio) in low-income countries and increases openness in high-income countries.

Our paper departs from Roy (2010) in two major ways. First, we use data on the capital-tolabor ratio instead of per capita income and can therefore address trade policies in the context of Heckscher-Ohlin type factor-abundance models. Second, we use trade-protection data for nonagricultural commodities instead of a broad measure of trade openness as the dependent variable in our regressions, for reasons discussed above.

The paper is organized as follows: The next section discusses the econometric model and the data sources; the third section reports the results for the baseline specification; the fourth section discusses the robustness tests; and the final section offers conclusions.

\section{ECONOMETRIC MODEL}

Based on the discussions in the previous section, we focus on these hypotheses:

The inequality hypothesis: All things equal, an increase in inequality will reduce trade protection in labor-abundant countries and increase trade protection in capital-abundant countries. Following Dutt and Mitra (2002), we estimate the following trade-protection equation for nonagricultural goods using cross-country measures on inequality and the capital-to-labor ratio:

$$
\begin{aligned}
& T R_{i}=\alpha_{0}+\alpha_{1} I N E Q_{i}+\alpha_{2} I N E Q_{i} \times(K / L)_{i} \\
& +\alpha_{3}(K / L)_{i}+\text { error }
\end{aligned}
$$

From equation (1), the marginal effect of the $I N E Q_{i}$ variable on $T R_{i}$ is $\alpha_{1}+\alpha_{2}(K / L)_{i}$. Consider a labor-abundant country. In this case, $(K / L)_{i}$ is small and the sign of the marginal effect of inequality is likely to be driven by the coefficient $\alpha_{1}$. Following the majority rule discussed above, in this country protection is expected to fall when inequality rises, giving the prior $\alpha_{1}<0$. Now consider a capital-abundant economy. In this case, $(K / L)_{i}$ is large and the sign of the marginal effect of inequality will be driven by the coeffi- 
cient $\alpha_{2}$. In this country, protection is expected to rise with inequality, giving the prior $\alpha_{2}>0$.

The ideology hypothesis: All things equal, an increase in the leftist political ideology of the government will reduce trade protection in laborabundant countries and raise trade protection in capital-abundant countries. Dutt and Mitra (2005) used a specification of the following form to test the interaction between political ideology and the capital-to-labor ratio:

$$
\begin{aligned}
& T R_{i}=\delta_{0}+\delta_{1} I_{i}+\delta_{2} I_{i} \times(K / L)_{i} \\
& +\delta_{3}(K / L)_{i}+\text { error, }
\end{aligned}
$$

where $I D_{i}$ denotes the political ideology of the government. If $I D_{i}$ increases with left-wing ideology, then according to the ideology hypothesis, $\delta_{1}<0$ and $\delta_{2}>0$. In a related work, Dutt and Mitra (2006) combine the inequality and ideology hypotheses to test for the joint effect of the majority rule and political ideology on trade policy. We add a third hypothesis.

The corruption hypothesis: All things equal, if corruption has an anti-labor and pro-capital effect on trade policy, an increase in corruption will increase trade protection in labor-abundant countries and reduce trade protection in capitalabundant countries. (Conversely, if corruption has a pro-labor and anti-capital effect on trade policy, an increase in corruption will reduce trade protection in labor-abundant countries and increase trade protection in capital-abundant countries.)

The following specification tests for the differential effects of corruption on trade protection in labor-abundant and capital-abundant countries:

$$
\begin{aligned}
& \mathrm{TR}_{i}=\gamma_{0}+\gamma_{1} \mathrm{CORR}_{i}+\gamma_{2} \mathrm{CORR}_{i} \times(K / L)_{i} \\
& +\gamma_{3}(K / L)_{i}+\text { error, }
\end{aligned}
$$

where $C O R R_{i}$ is a measure of the level of corruption in country $i$.

If a higher level of corruption is associated with greater influence for pro-capital lobby groups (away from the median voter) in the design of trade policy, then we should expect $\gamma_{1}>0$ and $\gamma_{2}<0$. Figure 1 presents scatter plots of countries for two different protection measures-the Overall Trade Restrictive Index (OTRI) (top panels) and the weighted average tariff (bottom panels) against an average measure of corruption (for the years 1996, 1998, and 2000) obtained from the World Governance Indicators. For the OTRI, higher values of corruption seem to be associated with greater trade protection in general, with the effect of corruption being higher for capitalabundant countries (i.e., countries with greater than the median capital-to-labor ratio for the sample). For the weighted average tariff, higher values of corruption seem to increase tariff protection more in labor-abundant countries (i.e., countries with less than the median capital-tolabor ratio for the sample) than capital-abundant countries. Thus, the effect of corruption on trade policy is an open-ended question, and the signs for $\gamma_{1}$ and $\gamma_{2}$ can suggest whether it is beneficial or harmful to the interests of labor-the median voter.

We also address complementarity versus substitutability of each of the individual hypotheses. If inequality, ideology, and corruption are correlated with each other, then the individual models might be substitutes for one another. However, it is possible that each individual hypothesis conveys additional information, so that a comprehensive model incorporating all three might explain trade policy better. Thus, the following comprehensive specification nests all three hypotheses:

$$
\begin{aligned}
& T R_{i}=\beta_{0}+\beta_{1} I N E Q_{i}+\beta_{2} I N E Q_{i} \times(K / L)_{i} \\
(4) \quad & \beta_{3} I D_{i}+\beta_{4} I D_{i} \times(K / L)_{i}+\beta_{5} C O R R_{i} \\
& +\beta_{6} C_{C O R R_{i}} \times(K / L)_{i}+\beta_{7}(K / L)_{i}+\text { error. }
\end{aligned}
$$

Based on Bayesian and non-Bayesian criteria and the goodness of fit measured by (adjusted) $R^{2}$, our results indicate that the comprehensive model dominates each of the individual hypotheses. Moreover, while we find substantial support for the inequality and the corruption hypotheses in the comprehensive model, we do not find significant support for the ideology hypothesis in predicting non-agricultural trade protection.

We use three separate measures of trade protection for non-agricultural commodities (obtained from the newly constructed 2008 World Trade Indicators from the World Bank) as dependent 


\section{Figure 1}

\section{Corruption and Trade Protection}
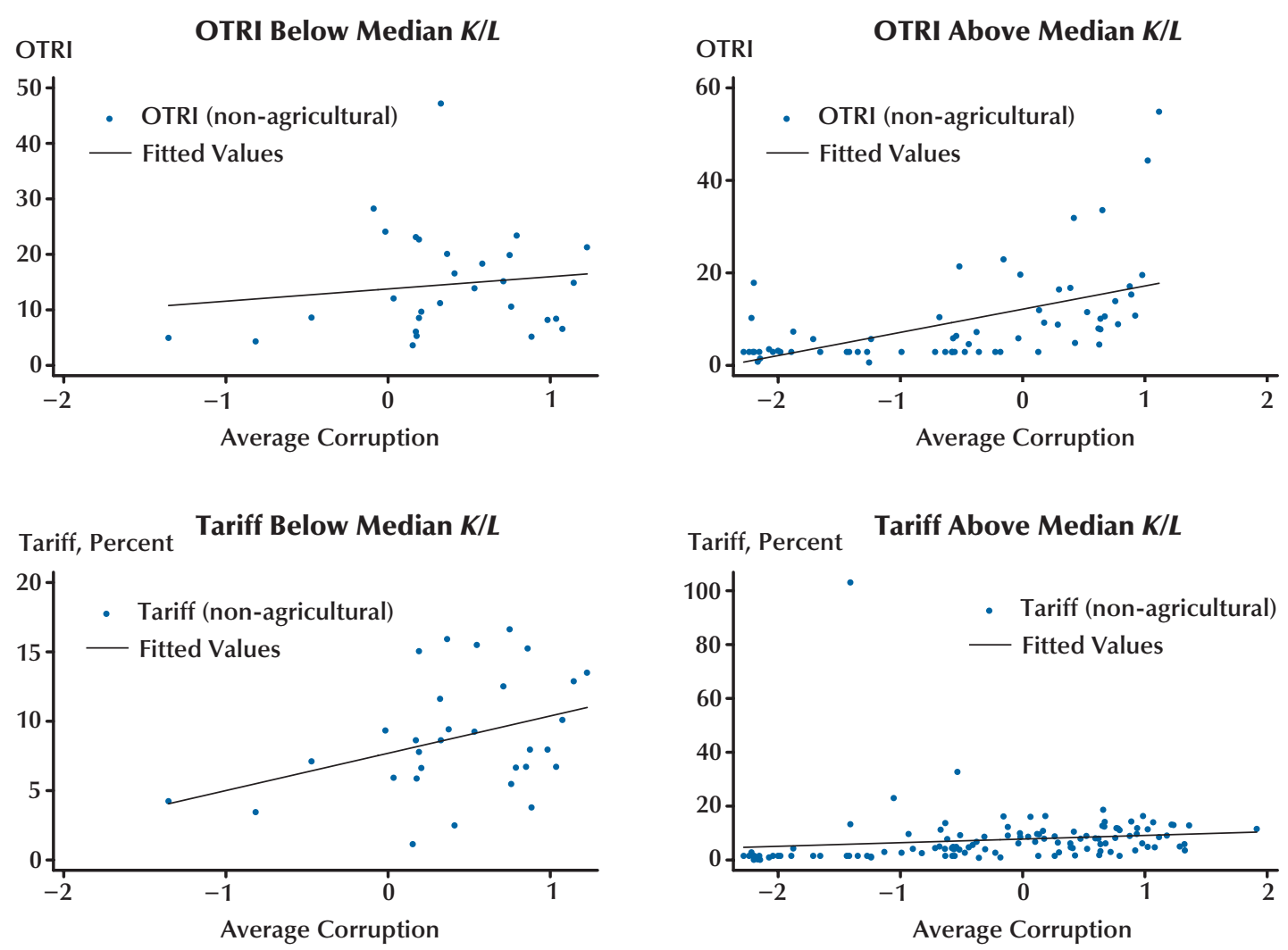

variables: (i) OTRI, (ii) the simple average tariff, and (iii) the weighted average tariff. The OTRI is a summary measure of the impact of each country's trade policy on its aggregate imports. It is the uniform tariff that, if imposed on imports in place of the existing structure of protection, would leave aggregate imports at their current level (Kee, Nicita, and Olarreaga, 2009). ${ }^{1}$ We use the average value of the OTRI for 2006 and 2007, the only years for which data are available. The simple average tariff rate is the average of all the

1 Coughlin (2010) provides an excellent review of the different World Bank trade restrictive indices. Given that non-tariff barriers might provide more protection than tariffs, as in the case of certain developed countries (e.g., the United States or the European Union), it might be misleading to focus on tariffs only. Thus, in addition to the tariff measures, we also use the OTRI measure as another trade policy indicator in our regressions. applied tariff rates on non-agricultural commodities that a country applies to its trading partners. However, this includes tariff lines where there are no trade flows. Thus, for comparison we include another dependent variable- the tradeweighted average tariff rate. Using these different protection measures ensures that our results are robust to alternative measures of trade protection. For both the simple and weighted tariffs, we use the average during the period 2001-07.

Data on asset inequality are adopted from Easterly (2007). The measure for the assetinequality variable is the average adjusted Gini coefficient during the period $1960-98 .^{2}$ Data on political ideology are from the Database of Politi-

2 Easterly (2007) contains an elaborate discussion on the construction and applicability of this inequality measure. 
cal Institutions (DPI) based on Beck et al. (2001), which is a large cross-country database of political institutions compiled by the Development

Research Group of the World Bank, covering 178 countries between 1975 and 2009. The ideological orientation variable in the DPI is recoded as

follows to reflect the extent to which the relevant government authority (presidential or parliamentary) can be classified as leftist: Left wing $=3$, centrist $=2$, and right wing $=1$; hence, the higher numbers signify more-leftist orientation. We use the average of the variable between 1991 and 2000.

Our baseline specification presents results using the Nehru-Dhareshwar (Nehru and Dhareshwar, 1993) capital-to-labor ratio data adopted from Dutt and Mitra (2002) that use the average value of the capital-to-labor ratio for the 1980s. The capital-to-labor ratio was calculated by dividing Nehru-Dhareshwar capital stock data (Nehru and Dhareshwar, 1993) by the labor supply. The latter is defined as the population between the ages 15 and 64, according to the World Development Indicators.

Subsequently, we performed robustness checks using, respectively, the Summers-Heston and the Easterly-Levine capital-per-worker data for the 1980s (both adopted from Dutt and Mitra, 2002). ${ }^{3}$ The corruption measure was obtained from the World Governance Indicators created by Kaufmann, Kraay, and Mastruzzi (2010), who have constructed six broad aggregates that measure governance for over 200 countries starting in 1996. We use the "control of corruption" indicator, which measures perceptions of corruption, and take the average of the index for the years 1996, 1998, and 2000. ${ }^{4}$ (See the Data Appendix for variables and sources.) The corruption index is standardized to have zero mean and standard deviation 1 in the sample, with higher values

\footnotetext{
3 The Summers-Heston data are in constant 1985 international dollars. The Easterly-Levine data are constructed from the SummersHeston disaggregated sectoral investment data along with disaggregated sector-level depreciation. The Nehru-Dhareshwar data include the largest number of countries, followed by the SummersHeston data and the Easterly-Levine data.

4 The control-of-corruption indicator is a measure of the extent to which public power is exercised for private gain, including both petty and grand forms of corruption, as well as "capture" of the state by elites and private interests.
}

representing better governance. For easy exposition, we multiply the index by -1 , such that higher values of the index denote greater corruption.

Thus, data for the explanatory variables are lagged to those for the dependent variables. The trade policy measures our paper seeks to explain are from the 2001-07 period, while those of the important explanatory variables (i.e., inequality, political ideology, corruption, and the capital-tolabor ratio) all predate the protection measures in that the latest data for these variables are for the year 2000. This rules out the possibility of any feedback effect that the dependent variables might have on the explanatory variables in our dataset. $^{5}$

\section{SUMMARY STATISTICS AND REGRESSION RESULTS}

Table 1A presents summary statistics for the major variables of interest. Hong Kong turns out to be the most open country, with OTRI $=0.6$ and zero values for the two tariff measures. Singapore and Macao also have zero values for the weighted and unweighted tariffs, respectively. ${ }^{6}$ In general, low-income countries seem to have higher trade protection compared with highincome countries. Thus, Tanzania, Djibouti, and Bermuda have the highest levels for the OTRI, simple average tariff, and weighted average tariff, respectively. The inequality measure ranges from a minimum of 23.97 for Mongolia to a maximum

5 This was consciously done to circumvent the problem of finding suitable instruments for all the explanatory variables. Obviously, for the (suspected) endogenous variables we needed to have at least four separate variables that (i) are individually highly correlated with each of the explanatory variables and (ii) satisfy the over-identifying restrictions (i.e., not correlated with the error term in the various specifications). Satisfying both restrictions for four separate explanatory variables would be a tall order. (See Murray, 2006, for a detailed discussion in this regard.) It is notoriously difficult to find instrument(s) for corruption alone in equations of trade protection or trade openness (see, e.g., Azfar, 2002) that satisfy the overidentifying restrictions. On these grounds, we decided to use lagged data for the explanatory variables that predate the dependent variables, such that the explanatory variables used in the study are not affected by feedback effects from trade policy on income distribution or the production structure.

${ }^{6}$ We addressed the issue of outliers in our data by running regressions after dropping Hong Kong, Macao, and Singapore from the pool of countries. Our major results involving the signs and the significance of the coefficients remain unaffected. 
Table 1A

Summary Statistics

\begin{tabular}{|c|c|c|c|c|c|}
\hline & Observations & Mean & Standard deviation & Minimum & Maximum \\
\hline OTRI & 95 & 10.80 & 10.22 & 0.6 & 54.9 \\
\hline Simple average tariff & 174 & 9.01 & 6.31 & 0 & 32.53 \\
\hline Weighted average tariff & 174 & 7.74 & 7.46 & 0 & 66.65 \\
\hline Inequality & 130 & 42.23 & 9.10 & 23.97 & 67.46 \\
\hline Ideology & 125 & 2.08 & 0.79 & 1 & 3 \\
\hline Corruption & 184 & 0.02 & 0.99 & -2.28 & 1.91 \\
\hline In(Nehru-Dhareshwar K/L) & 75 & 9.47 & 1.95 & 5.67 & 15.99 \\
\hline In(Easterly-Levine $K / L)$ & 58 & 9.29 & 1.35 & 5.45 & 11.73 \\
\hline In(Summers-Heston $K / L)$ & 63 & 9.10 & 1.28 & 5.33 & 11.05 \\
\hline
\end{tabular}

\section{Table 1B}

\section{Correlation Matrix}

\begin{tabular}{|c|c|c|c|c|c|c|c|}
\hline & OTRI & $\begin{array}{c}\text { Simple } \\
\text { average } \\
\text { tariff }\end{array}$ & $\begin{array}{c}\text { Weighted } \\
\text { average } \\
\text { tariff }\end{array}$ & Inequality & Ideology & Corruption & $\ln (N D K / L)$ \\
\hline OTRI & 1 & & & & & & \\
\hline Simple average tariff & 0.82 & 1 & & & & & \\
\hline Weighted average tariff & 0.81 & 0.97 & 1 & & & & \\
\hline Inequality & 0.45 & 0.49 & 0.45 & 1 & & & \\
\hline Ideology & -0.07 & -0.04 & -0.09 & -0.11 & 1 & & \\
\hline Corruption & 0.69 & 0.80 & 0.77 & 0.72 & -0.09 & 1 & \\
\hline In(Nehru-Dhareshwar $K / L)$ & -0.69 & -0.79 & -0.72 & -0.69 & -0.04 & -0.82 & 1 \\
\hline In(Easterly-Levine $K / L)$ & -0.69 & -0.79 & -0.71 & -0.68 & -0.08 & -0.78 & 0.89 \\
\hline In(Summers-Heston $K / L)$ & -0.70 & -0.80 & -0.71 & -0.67 & -0.07 & -0.79 & 0.90 \\
\hline
\end{tabular}

of 67.46 for Gabon. The corruption measure ranges from a minimum of -2.28 for Finland to a maximum of 1.91 for Zaire. Other results for lowincome countries are similar to those for trade protection: These countries have higher levels of asset inequality (mainly in sub-Saharan Africa) and higher levels of corruption. Table $1 \mathrm{~B}$ reports the correlation levels between the dependent variables and the different explanatory variables. All trade-protection measures are correlated with higher asset inequality and greater corruption, with the correlation coefficient varying from 0.45 to 0.49 for inequality and 0.69 to 0.80 for corruption. On the other hand, the ideology variable seems to be weakly negatively correlated with the protection measures. Corruption is highly correlated with income inequality $(r=0.72)$ for the minimum number of observations for which all the variables are present in the sample $(n=34)$. Thus, not including corruption as an explanatory variable would lead to an omitted variable bias in estimating trade policy.

Table 2A reports results for the inequality hypothesis for non-agricultural goods using the 


\section{Table 2A}

\section{Inequality Hypothesis}

\begin{tabular}{|c|c|c|c|}
\hline Dep & $\begin{array}{l}\text { endent variable: } \\
\text { OTRI }\end{array}$ & $\begin{array}{l}\text { Dependent variable: } \\
\text { Simple average tariff }\end{array}$ & $\begin{array}{l}\text { Dependent variable: } \\
\text { Weighted average tariff }\end{array}$ \\
\hline Inequality & $\begin{array}{c}-2.59 * * * \\
(0.87)\end{array}$ & $\begin{array}{l}-1.17^{* * *} \\
(0.30)\end{array}$ & $\begin{array}{c}-0.73^{* * *} \\
(0.26)\end{array}$ \\
\hline Inequality $\times \ln ($ Nehru-Dhareshwar $K / L)$ & $\begin{array}{l}0.31^{* * *} \\
(0.10)\end{array}$ & $\begin{array}{l}0.14^{* * *} \\
(0.03)\end{array}$ & $\begin{array}{l}0.091^{* * *} \\
(0.02)\end{array}$ \\
\hline In(Nehru-Dhareshwar $K / L)$ & $\begin{array}{c}-13.70^{* * *} \\
(3.50)\end{array}$ & $\begin{array}{l}-7.60^{* * *} \\
(1.27)\end{array}$ & $\begin{array}{l}-5.13^{* * *} \\
(1.12)\end{array}$ \\
\hline Akaike information criteria (AIC) & 438.40 & 414.70 & 386.30 \\
\hline Bayesian information criteria (BIC) & 446.80 & 423.70 & 395.40 \\
\hline Adjusted $R^{2}$ & 0.29 & 0.46 & 0.42 \\
\hline Ramsey RESET test $p$-value & 0.01 & 0.40 & 0.61 \\
\hline Number of observations & 60 & 71 & 71 \\
\hline
\end{tabular}

NOTE: Robust or bootstrap standard errors are in parentheses. Low $p$-values of the Ramsey RESET test indicate misspecification; *** indicates significance at the 1 percent level.

\section{Table 2B}

\section{Ideology Hypothesis}

\begin{tabular}{|c|c|c|c|}
\hline Dep & $\begin{array}{l}\text { Ident variable: } \\
\text { OTRI }\end{array}$ & $\begin{array}{l}\text { Dependent variable: } \\
\text { Simple average tariff }\end{array}$ & $\begin{array}{l}\text { Dependent variable: } \\
\text { Weighted average tariff }\end{array}$ \\
\hline Ideology & $\begin{array}{l}-17.2 \\
(12.00)\end{array}$ & $\begin{array}{c}-10.2^{* *} \\
(4.96)\end{array}$ & $\begin{array}{c}-6.26^{*} \\
(3.43)\end{array}$ \\
\hline Ideology $\times \ln ($ Nehru-Dhareshwar $K / L)$ & $\begin{array}{c}2.41^{*} \\
(1.39)\end{array}$ & $\begin{array}{c}1.35^{* *} \\
(0.56)\end{array}$ & $\begin{array}{c}0.83^{* *} \\
(0.37)\end{array}$ \\
\hline In(Nehru-Dhareshwar $K / L)$ & $\begin{array}{c}-6.42^{* *} \\
(2.90)\end{array}$ & $\begin{array}{l}-4.84^{* * *} \\
(1.29)\end{array}$ & $\begin{array}{l}-3.32^{* * *} \\
(0.89)\end{array}$ \\
\hline AIC & 376.70 & 352.80 & 327.40 \\
\hline $\mathrm{BIC}$ & 384.40 & 361.10 & 335.70 \\
\hline Adjusted $R^{2}$ & 0.16 & 0.38 & 0.35 \\
\hline Ramsey RESET test $p$-value & 0.0002 & 0.001 & 0.01 \\
\hline Number of observations & 50 & 59 & 59 \\
\hline
\end{tabular}

equation (1) specification. For all measures of trade protection, the inequality variable is negative and significant and the interaction term between inequality and the capital-to-labor ratio (measured by the Nehru-Dhareshwar capital-to-labor ratio data) is positive and significant (both at the 1 per- cent level). Thus, greater inequality is associated with reduced trade protection for non-agricultural goods in labor-abundant countries and more trade protection for such goods in capital-abundant countries. Given that the median voter (or labor) will gain from more trade in labor-abundant 
Table 2C

\section{Corruption Hypothesis}

\begin{tabular}{lccc} 
& $\begin{array}{c}\text { Dependent variable: } \\
\text { OTRI }\end{array}$ & $\begin{array}{c}\text { Dependent variable: } \\
\text { Simple average tariff }\end{array}$ & $\begin{array}{c}\text { Dependent variable: } \\
\text { Weighted average tariff }\end{array}$ \\
\hline Corruption & -10.50 & 4.02 & $4.85^{+}$ \\
& $(8.92)$ & $(3.40)$ & $(2.93)$ \\
Corruption $\times \ln ($ Nehru-Dhareshwar $K / L)$ & $1.53^{*}$ & -0.01 & -0.19 \\
& $(0.87)$ & $(0.30)$ & $(0.26)$ \\
In $($ Nehru-Dhareshwar $K / L)$ & 0.85 & -0.10 & -0.20 \\
& $(0.84)$ & $(0.39)$ & $(0.27)$ \\
AIC & 448.00 & 436.50 & 404.30 \\
BIC & 456.50 & 445.70 & 413.60 \\
Adjusted $R^{2}$ & 0.34 & 0.50 & 0.47 \\
Ramsey RESET test $p$-value & 0.02 & 0.32 & 0.49 \\
Number of observations & 62 & 74 & 74
\end{tabular}

NOTE: Robust or bootstrap standard errors are in parentheses. Low Ramsey RESET test $p$-values indicate misspecification;

${ }^{+}$and ${ }^{*}$ indicate significance at the 15 and 10 percent levels, respectively.

countries and lose from more trade in capitalabundant countries, majority interests may be an important factor in driving non-agricultural trade protection. Based on the results in Table 2B, nonagricultural tariff protection also lends some support to the ideology hypothesis. For both the simple and weighted average tariffs, the ideology variable is negative and significant, while the interaction term between ideology and the capitalto-labor ratio is positive and significant. Given that the ideology measure captures pro-worker interests, left-wing political ideology is associated with pro-labor non-agricultural trade policies in both labor-abundant and capital-abundant countries. These results provide support for the conclusions of Dutt and Mitra (2002, 2005) regarding non-agricultural commodities. However, based on the results in Table 2C, we do not find any evidence of a correlation between corruption and trade protection because both corruption and the interaction term (between corruption and the capital-to-labor ratio) are generally not statistically significant.

Given our previous findings on the high degree of correlation between corruption and trade protection and corruption and inequality, we suspect misspecification problems based on results from the stand-alone regressions. Thus, we estimate a comprehensive model for trade protection with inequality, ideology, and corruption along with their interactions with the capital-to-labor ratio as explanatory variables as in equation (4).

The results are reported in Table 3. For trade protection measured by the OTRI, however, none of the explanatory variables turn out to be significant. Except for inequality and its interaction with the capital-to-labor ratio, all other explanatory variables in this regression have signs opposite to those anticipated. Moreover, as indicated by the Ramsey RESET test, there seem to be misspecification problems in the comprehensive model for the OTRI since the null hypothesis of no omitted variables is rejected based on a significant $F$-test. The inequality hypothesis is validated by both the tariff measures. However, we do not find any support for the ideology hypothesis.

The corruption variable, however, is positive and significant at the 10 percent level for the simple tariff and at the 5 percent level for the weighted tariff. The interaction term between corruption and the capital-to-labor ratio is negative in both tariff regressions and statistically significant for the weighted tariff. Thus, we find some evidence that corruption is associated with 
Table 3

Comprehensive Model

\begin{tabular}{|c|c|c|c|}
\hline Depe & $\begin{array}{l}\text { ndent variable: } \\
\text { OTRI }\end{array}$ & $\begin{array}{l}\text { Dependent variable: } \\
\text { Simple average tariff }\end{array}$ & $\begin{array}{l}\text { Dependent variable: } \\
\text { Weighted average tariff }\end{array}$ \\
\hline Inequality & $\begin{array}{l}-0.03 \\
(1.36)\end{array}$ & $\begin{array}{l}-0.73^{* *} \\
(0.36)\end{array}$ & $\begin{array}{c}-0.63^{*} \\
(0.34)\end{array}$ \\
\hline Inequality $\times \ln ($ Nehru-Dhareshwar $K / L)$ & $\begin{array}{c}0.01 \\
(0.13)\end{array}$ & $\begin{array}{c}0.07^{*} \\
(0.04)\end{array}$ & $\begin{array}{l}0.063^{*} \\
(0.04)\end{array}$ \\
\hline Ideology & $\begin{array}{c}5.57 \\
(10.70)\end{array}$ & $\begin{array}{l}-1.01 \\
(3.18)\end{array}$ & $\begin{array}{l}-0.31 \\
(2.37)\end{array}$ \\
\hline Ideology $\times \ln ($ Nehru-Dhareshwar $K / L)$ & $\begin{array}{c}-0.06 \\
(0.99)\end{array}$ & $\begin{array}{c}0.30 \\
(0.30)\end{array}$ & $\begin{array}{c}0.14 \\
(0.22)\end{array}$ \\
\hline Corruption & $\begin{array}{l}-1.60 \\
(9.64)\end{array}$ & $\begin{array}{c}7.98^{*} \\
(4.08)\end{array}$ & $\begin{array}{l}8.64^{* *} \\
(3.27)\end{array}$ \\
\hline Corruption $\times \ln ($ Nehru-Dhareshwar $K / L)$ & $\begin{array}{c}0.72 \\
(0.95)\end{array}$ & $\begin{array}{c}-0.48 \\
(0.40)\end{array}$ & $\begin{array}{c}-0.62^{*} \\
(0.32)\end{array}$ \\
\hline In(Nehru-Dhareshwar $K / L)$ & $\begin{array}{c}0.93 \\
(7.37)\end{array}$ & $\begin{array}{l}-4.41^{* *} \\
(1.94)\end{array}$ & $\begin{array}{l}-3.57^{* *} \\
(1.71)\end{array}$ \\
\hline AIC & 360.20 & 325.60 & 306.50 \\
\hline $\mathrm{BIC}$ & 375.50 & 342.20 & 323.10 \\
\hline Adjusted $R^{2}$ & 0.44 & 0.63 & 0.57 \\
\hline Ramsey RESET test $p$-value & 0.02 & 0.23 & 0.15 \\
\hline Number of observations & 50 & 59 & 59 \\
\hline
\end{tabular}

greater protection in labor-abundant countries and reduced protection in capital-abundant countries. The Ramsey RESET test does not report any misspecification problem for the tariff regressions. The comprehensive model explains a larger portion of the variation for each dependent variable in comparison with the stand-alone models in equations (1) through (3), as indicated by the higher values of the adjusted $R^{2}$. Also, for all dependent variables, both the Akaike information criterion (AIC) and the Bayesian information criterion (BIC) select the comprehensive model over the models of the individual hypotheses.

\section{ROBUSTNESS CHECKS}

First, we try to address the issue of omitted variable bias by controlling for various countrylevel characteristics that might be correlated with the important explanatory variables in the regressions. We use three control variables found to be important determinants of trade policy in previous studies: an inverse index of democracy (the Gastil index of political rights), a measure of human capital, and the logarithm of per capita income. The logic behind introducing these control variables is the following: The level of political rights has been found to be an important predictor of trade policy, because democratic regimes may differ from dictatorial regimes in terms of income distribution considerations (Milner and Kubota, 2005). Literacy (or human capital) measured by years of schooling may also be an important determinant of trade protection (openness) of countries. For example, educated individuals may be better able to understand the deadweight costs of trade protection that favors special interest groups (Dutt and Mitra, 2002). Finally, per capita income has often been used in 
the literature because low-income countries may use trade policy (tariff barriers) to generate revenue when the income tax base is small.

The political rights measure is an average of the score for political rights and civil rights between 1991 and 2000 from Freedom House, with higher values denoting less political freedom. The measure of human capital, adopted from Neeman, Paserman, and Simhon (2008), is an index of human capital based on a piecewise linear function of total years of schooling for the population age 25 and above, as obtained from Barro and Lee (2000). Data on real per capita income for countries are from the World Development Indicators. We also introduce several regional dummies based on groupings from the World Trade Indicators to capture geographical or structural characteristics otherwise not incorporated in the regressions.

Results for the comprehensive model with the regional dummy variables ${ }^{7}$ included are reported in column A of Tables 4 through 6 . Both the inequality and corruption hypotheses find strong support from the two tariff measures: The interaction term between the capital-to-labor ratio and each hypothesis is significant at the 1 percent level. None of the explanatory variables are significant for the OTRI. Moreover, the ideology hypothesis does not find support in any of the regressions. The results remain unchanged once we control for political rights, human capital, and per capita income (see column B of Tables 4 through 6). None of the control variables are significant. A striking feature of the model is that for cross-country data it can explain a substantial portion of variation for both tariff measures, as characterized by the (adjusted) $R^{2}$ values of 0.82 and 0.83 for the weighted and unweighted tariffs, respectively.

We also carry out further robustness checks by introducing additional controls that might be correlated with trade protection as well as the institutional structure of the economy. These include the distance of the country from the equator, measured by its latitude; dummy variables

7 The regional groupings that were found to be significant on the basis of a Wald test and, hence, the regressions include East Asia and the Pacific, sub-Saharan Africa, South Asia, the Middle East, and Latin America. indicating the religious composition of the population; the legal origin; and the ethno-linguistic fractionalization index, which has been found to be an important determinant of corruption in previous studies (La Porta et al., 1999). Data on all the variables are adopted from Neeman, Paserman, and Simhon (2008). The results are reported in column $\mathrm{C}$ of Tables 4 through 6 . The inclusion of these variables essentially has no impact on our previous conclusions regarding the inequality and corruption hypotheses. Interestingly, we find support for the ideology hypothesis from the unweighted tariff measure since both ideology and its interaction with the capital-to-labor ratio are significant (at the 5 percent level). Moreover, the values of the (adjusted) $R^{2}$ for the tariff measures are higher. The results also indicate that the comprehensive model does not receive much support from the OTRI protection measure in that none of the explanatory variables (inequality, political ideology, and corruption) turn out to be significant. One explanation is that the OTRI is a summary measure that incorporates both tariff and non-tariff barriers, and because non-tariff barriers are more prevalent in high-income (capitalabundant) countries than low-income (laborabundant) countries, there might not be substantial variability in the data for the model to significantly explain variations in the OTRI. Moreover, the OTRI measure is available for a much smaller sample of countries (95) compared with that for the tariff measures (174).

Finally, we use the Easterly-Levine and the Summers-Heston capital-per-worker data as explanatory variables instead of the NehruDhareshwar capital-per-worker data. Interestingly, we find strong support for both the inequality and the corruption hypotheses from the OTRI trade policy measure (see columns D and E of Table 6). For regressions with the tariff measures, we also find support for these hypotheses when we use the Summers-Heston capital-to-labor ratio as an explanatory variable (see column $\mathrm{E}$ of Tables 4 and 5). However, the corruption hypothesis does not receive significant support from the simple or weighted tariff regressions using the Easterly-Levine capital-to-labor ratio because both corruption and its interaction term do not 


\section{Table 4}

\section{Simple Average Tariff}

\begin{tabular}{|c|c|c|c|c|c|}
\hline & (A) & (B) & (C) & (D) & (E) \\
\hline Inequality & $\begin{array}{c}-1.15^{* * *} \\
(0.30)\end{array}$ & $\begin{array}{c}-1.13^{* * *} \\
(0.35)\end{array}$ & $\begin{array}{l}-1.44^{* * *} \\
(0.40)\end{array}$ & $\begin{array}{c}-1.86^{* *} \\
(0.79)\end{array}$ & $\begin{array}{c}-1.58^{*} \\
(0.78)\end{array}$ \\
\hline Inequality $\times \ln ($ Nehru-Dhareshwar $K / L)$ & $\begin{array}{l}0.11^{* * *} \\
(0.03)\end{array}$ & $\begin{array}{l}0.11^{* * *} \\
(0.04)\end{array}$ & $\begin{array}{l}0.15^{* * *} \\
(0.04)\end{array}$ & & \\
\hline Ideology & $\begin{array}{c}-3.36 \\
(2.38)\end{array}$ & $\begin{array}{r}-3.93^{\dagger} \\
(2.52)\end{array}$ & $\begin{array}{l}-4.74^{* *} \\
(2.24)\end{array}$ & $\begin{array}{c}2.80 \\
(4.89)\end{array}$ & $\begin{array}{c}0.15 \\
(4.21)\end{array}$ \\
\hline Ideology $\times \ln ($ Nehru-Dhareshwar $K / L)$ & $\begin{array}{c}0.35 \\
(0.25)\end{array}$ & $\begin{array}{r}0.40^{+} \\
(0.26)\end{array}$ & $\begin{array}{l}0.50^{* *} \\
(0.24)\end{array}$ & & \\
\hline Corruption & $\begin{array}{l}10.00^{* * *} \\
(2.59)\end{array}$ & $\begin{array}{l}9.78^{* * *} \\
(2.67)\end{array}$ & $\begin{array}{l}14.40^{* * *} \\
(3.41)\end{array}$ & $\begin{array}{l}11.10^{+} \\
(6.80)\end{array}$ & $\begin{array}{l}15.70^{* *} \\
(6.86)\end{array}$ \\
\hline Corruption $\times \ln ($ Nehru-Dhareshwar $K / L)$ & $\begin{array}{c}-0.86^{* * *} \\
(0.26)\end{array}$ & $\begin{array}{c}-0.84^{* * *} \\
(0.26)\end{array}$ & $\begin{array}{l}-1.41^{* * *} \\
(0.34)\end{array}$ & & \\
\hline In(Nehru-Dhareshwar $K / L)$ & $\begin{array}{l}-5.98^{* * *} \\
(1.54)\end{array}$ & $\begin{array}{l}-5.81^{* * *} \\
(1.78)\end{array}$ & $\begin{array}{l}-7.87^{* * *} \\
(2.11)\end{array}$ & & \\
\hline In(Real GDP per capita) & & $\begin{array}{c}-0.86 \\
(0.81)\end{array}$ & $\begin{array}{c}-0.61 \\
(0.92)\end{array}$ & $\begin{array}{c}-0.53 \\
(1.12)\end{array}$ & $\begin{array}{c}1.06 \\
(1.02)\end{array}$ \\
\hline Political rights & & $\begin{array}{c}-0.13 \\
(0.56)\end{array}$ & $\begin{array}{c}-0.55 \\
(0.53)\end{array}$ & $\begin{array}{c}0.45 \\
(1.16)\end{array}$ & $\begin{array}{c}0.30 \\
(0.91)\end{array}$ \\
\hline Human capital & & $\begin{array}{c}1.96 \\
(2.26)\end{array}$ & $\begin{array}{c}0.72 \\
(3.02)\end{array}$ & $\begin{array}{c}-2.93 \\
(4.75)\end{array}$ & $\begin{array}{c}2.63 \\
(4.03)\end{array}$ \\
\hline Inequality $\times \ln ($ Easterly-Levine $K / L)$ & & & & $\begin{array}{c}0.17^{*} \\
(0.09)\end{array}$ & \\
\hline Ideology $\times \ln ($ Easterly-Levine $K / L)$ & & & & $\begin{array}{c}-0.37 \\
(0.51)\end{array}$ & \\
\hline Corruption $\times \ln ($ Easterly-Levine $K / L)$ & & & & $\begin{array}{c}-1.06 \\
(0.73)\end{array}$ & \\
\hline In(Easterly-Levine $K / L$ ) & & & & $\begin{array}{r}-6.17^{+} \\
(3.86)\end{array}$ & \\
\hline Inequality $\times \ln ($ Summers-Heston K/L) & & & & & $\begin{array}{c}0.16^{*} \\
(0.09)\end{array}$ \\
\hline Ideology $\times \ln ($ Summers-Heston $K / L)$ & & & & & $\begin{array}{c}0.01 \\
(0.45)\end{array}$ \\
\hline Corruption $\times \ln ($ Summers-Heston $K / L)$ & & & & & $\begin{array}{c}-1.52^{*} \\
(0.75)\end{array}$ \\
\hline In(Summers-Heston $K / L$ ) & & & & & $\begin{array}{c}-8.43^{*} \\
(4.50)\end{array}$ \\
\hline Regional groupings & Yes & Yes & Yes & Yes & Yes \\
\hline $\begin{array}{l}\text { Latitude, religion dummies, legal } \\
\text { origin dummies, fractionalization index }\end{array}$ & & & Yes & Yes & Yes \\
\hline AIC & 282.20 & 286.60 & 283.80 & 214.50 & 239.70 \\
\hline $\mathrm{BIC}$ & 309.20 & 319.80 & 329.50 & 252.50 & 279.50 \\
\hline Adjusted $R^{2}$ & 0.83 & 0.83 & 0.84 & 0.80 & 0.77 \\
\hline Number of observations & 59 & 59 & 59 & 45 & 49 \\
\hline
\end{tabular}


Table 5

Weighted Average Tariff

\begin{tabular}{|c|c|c|c|c|c|}
\hline & (A) & (B) & (C) & (D) & (E) \\
\hline Inequality & $\begin{array}{c}-1.01^{* * *} \\
(0.29)\end{array}$ & $\begin{array}{c}-1.20^{* * *} \\
(0.30)\end{array}$ & $\begin{array}{c}-1.26^{* * *} \\
(0.34)\end{array}$ & $\begin{array}{r}-1.00^{+} \\
(0.65)\end{array}$ & $\begin{array}{c}-1.02 * \\
(0.59)\end{array}$ \\
\hline Inequality $\times \ln ($ Nehru-Dhareshwar $K / L)$ & $\begin{array}{l}0.10^{* * *} \\
(0.03)\end{array}$ & $\begin{array}{l}0.12^{* * *} \\
(0.03)\end{array}$ & $\begin{array}{l}0.13^{* * *} \\
(0.04)\end{array}$ & & \\
\hline Ideology & $\begin{array}{l}-2.20 \\
(1.99)\end{array}$ & $\begin{array}{c}-2.84 \\
(2.20)\end{array}$ & $\begin{array}{c}-2.84 \\
(2.09)\end{array}$ & $\begin{array}{c}3.23 \\
(3.76)\end{array}$ & $\begin{array}{c}2.84 \\
(3.56)\end{array}$ \\
\hline Ideology $\times \ln ($ Nehru-Dhareshwar $K / L)$ & $\begin{array}{c}0.20 \\
(0.21)\end{array}$ & $\begin{array}{c}0.25 \\
(0.23)\end{array}$ & $\begin{array}{c}0.26 \\
(0.23)\end{array}$ & & \\
\hline Corruption & $\begin{array}{l}10.00^{* * *} \\
(2.20)\end{array}$ & $\begin{array}{l}11.40^{* * *} \\
(2.16)\end{array}$ & $\begin{array}{l}12.40^{* * *} \\
(2.68)\end{array}$ & $\begin{array}{r}8.55^{\dagger} \\
(5.53)\end{array}$ & $\begin{array}{l}12.00^{* *} \\
(5.48)\end{array}$ \\
\hline Corruption $\times \ln ($ Nehru-Dhareshwar $K / L)$ & $\begin{array}{c}-0.91^{* * *} \\
(0.22)\end{array}$ & $\begin{array}{c}-1.04^{* * *} \\
(0.21)\end{array}$ & $\begin{array}{c}-1.19 * * * \\
(0.27)\end{array}$ & & \\
\hline In(Nehru-Dhareshwar $K / L)$ & $\begin{array}{l}-5.26^{* * *} \\
(1.51)\end{array}$ & $\begin{array}{l}-6.18^{* * *} \\
(1.58)\end{array}$ & $\begin{array}{c}-6.63^{* * *} \\
(1.88)\end{array}$ & & \\
\hline In(Real GDP per capita) & & $\begin{array}{c}-0.22 \\
(0.74)\end{array}$ & $\begin{array}{c}0.13 \\
(0.74)\end{array}$ & $\begin{array}{c}-0.24 \\
(0.83)\end{array}$ & $\begin{array}{c}0.35 \\
(0.74)\end{array}$ \\
\hline Political rights & & $\begin{array}{r}-0.68^{+} \\
(0.43)\end{array}$ & $\begin{array}{c}-0.85^{*} \\
(0.45)\end{array}$ & $\begin{array}{c}-0.64 \\
(1.08)\end{array}$ & $\begin{array}{c}-0.84 \\
(0.75)\end{array}$ \\
\hline Human capital & & $\begin{array}{c}-1.53 \\
(1.71)\end{array}$ & $\begin{array}{c}-3.68 * \\
(1.97)\end{array}$ & $\begin{array}{c}-7.27^{* *} \\
(2.76)\end{array}$ & $\begin{array}{l}-4.76^{*} \\
(2.68)\end{array}$ \\
\hline Inequality $\times \ln ($ Easterly-Levine $K / L)$ & & & & $\begin{array}{c}0.091 \\
(0.07)\end{array}$ & \\
\hline Ideology $\times \ln ($ Easterly-Levine $K / L)$ & & & & $\begin{array}{c}-0.47 \\
(0.41)\end{array}$ & \\
\hline Corruption $\times \ln ($ Easterly-Levine $K / L)$ & & & & $\begin{array}{c}-0.78 \\
(0.57)\end{array}$ & \\
\hline In(Easterly-Levine $K / L$ ) & & & & $\begin{array}{l}-2.83 \\
(2.82)\end{array}$ & \\
\hline Inequality $\times \ln ($ Summers-Heston K/L) & & & & & $\begin{array}{c}0.10^{+} \\
(0.07)\end{array}$ \\
\hline Ideology $\times \ln ($ Summers-Heston $K / L)$ & & & & & $\begin{array}{c}-0.39 \\
(0.38)\end{array}$ \\
\hline Corruption $\times \ln ($ Summers-Heston $K / L)$ & & & & & $\begin{array}{c}-1.13^{*} \\
(0.60)\end{array}$ \\
\hline In(Summers-Heston $K / L)$ & & & & & $\begin{array}{c}-4.12 \\
(3.44)\end{array}$ \\
\hline Regional groupings & Yes & Yes & Yes & Yes & Yes \\
\hline $\begin{array}{l}\text { Latitude, religion dummies, legal } \\
\text { origin dummies, fractionalization index }\end{array}$ & & & Yes & Yes & Yes \\
\hline AIC & 259.00 & 260.70 & 261.20 & 193.00 & 210.80 \\
\hline $\mathrm{BIC}$ & 286.00 & 293.90 & 306.90 & 231.00 & 250.60 \\
\hline Adjusted $R^{2}$ & 0.82 & 0.82 & 0.83 & 0.81 & 0.79 \\
\hline Number of observations & 59 & 59 & 59 & 45 & 49 \\
\hline
\end{tabular}

NOTE: Robust or bootstrap standard errors are in parentheses; ${ }^{\dagger},{ }^{*},{ }^{* *}$, and ${ }^{* * *}$ indicate significance at the $15,10,5$, and 1 percent levels, respectively. 
Table 6

\section{OTRI}

\begin{tabular}{|c|c|c|c|c|c|}
\hline & (A) & (B) & (C) & (D) & (E) \\
\hline Inequality & $\begin{array}{c}-0.94 \\
(1.63)\end{array}$ & $\begin{array}{c}0.29 \\
(2.18)\end{array}$ & $\begin{array}{c}1.12 \\
(2.97)\end{array}$ & $\begin{array}{l}-4.64^{* *} \\
(2.01)\end{array}$ & $\begin{array}{l}-4.07^{* * *} \\
(1.13)\end{array}$ \\
\hline Inequality $\times \operatorname{In}($ Nehru-Dhareshwar $K / L)$ & $\begin{array}{c}0.09 \\
(0.16)\end{array}$ & $\begin{array}{c}-0.04 \\
(0.21)\end{array}$ & $\begin{array}{c}-0.13 \\
(0.30)\end{array}$ & & \\
\hline Ideology & $\begin{array}{c}-2.10 \\
(9.66)\end{array}$ & $\begin{array}{c}-2.07 \\
(11.30)\end{array}$ & $\begin{array}{c}0.12 \\
(14.90)\end{array}$ & $\begin{array}{c}12.90 \\
(13.80)\end{array}$ & $\begin{array}{c}14.50 \\
(13.70)\end{array}$ \\
\hline Ideology $\times \ln ($ Nehru-Dhareshwar $K / L)$ & $\begin{array}{c}0.24 \\
(0.83)\end{array}$ & $\begin{array}{c}0.23 \\
(0.99)\end{array}$ & $\begin{array}{c}0.10 \\
(1.27)\end{array}$ & & \\
\hline Corruption & $\begin{array}{c}0.77 \\
(8.35)\end{array}$ & $\begin{array}{c}-6.63 \\
(11.60)\end{array}$ & $\begin{array}{c}-8.73 \\
(17.10)\end{array}$ & $\begin{array}{l}35.30^{* * *} \\
(10.20)\end{array}$ & $\begin{array}{l}44.00^{* * *} \\
(11.90)\end{array}$ \\
\hline Corruption $\times \ln ($ Nehru-Dhareshwar $K / L)$ & $\begin{array}{c}0.24 \\
(0.85)\end{array}$ & $\begin{array}{c}0.54 \\
(1.02)\end{array}$ & $\begin{array}{c}0.65 \\
(1.72)\end{array}$ & & \\
\hline In(Nehru-Dhareshwar $K / L)$ & $\begin{array}{c}-2.97 \\
(8.65)\end{array}$ & $\begin{array}{c}4.12 \\
(11.60)\end{array}$ & $\begin{array}{c}9.17 \\
(16.80)\end{array}$ & & \\
\hline In(Real GDP per capita) & & $\begin{array}{c}-3.94 \\
(2.69)\end{array}$ & $\begin{array}{c}-3.60 \\
(2.92)\end{array}$ & $\begin{array}{c}-0.95 \\
(2.07)\end{array}$ & $\begin{array}{c}0.49 \\
(1.72)\end{array}$ \\
\hline Political rights & & $\begin{array}{c}1.11 \\
(1.99)\end{array}$ & $\begin{array}{c}2.08 \\
(2.69)\end{array}$ & $\begin{array}{c}1.87 \\
(2.62)\end{array}$ & $\begin{array}{c}0.63 \\
(1.98)\end{array}$ \\
\hline Human capital & & $\begin{array}{c}-10.40 \\
(12.70)\end{array}$ & $\begin{array}{c}-14.10 \\
(14.90)\end{array}$ & $\begin{array}{c}0.80 \\
(7.10)\end{array}$ & $\begin{array}{c}-1.01 \\
(6.34)\end{array}$ \\
\hline Inequality $\times \ln ($ Easterly-Levine $K / L)$ & & & & $\begin{array}{l}0.46^{* *} \\
(0.21)\end{array}$ & \\
\hline Ideology $\times \ln ($ Easterly-Levine $K / L)$ & & & & $\begin{array}{c}-1.32 \\
(1.35)\end{array}$ & \\
\hline Corruption $\times \ln ($ Easterly-Levine $K / L)$ & & & & $\begin{array}{c}-3.97^{* * *} \\
(1.13)\end{array}$ & \\
\hline In(Easterly-Levine $K / L$ ) & & & & $\begin{array}{c}-19.40^{* *} \\
(8.01)\end{array}$ & \\
\hline Inequality $\times \ln$ (Summers-Heston K/L) & & & & & $\begin{array}{l}0.43^{* * *} \\
(0.13)\end{array}$ \\
\hline Ideology $\times \ln ($ Summers-Heston $K / L)$ & & & & & $\begin{array}{c}-1.37 \\
(1.39)\end{array}$ \\
\hline Corruption $\times \ln ($ Summers-Heston $K / L)$ & & & & & $\begin{array}{l}-4.79 * * * \\
(1.24)\end{array}$ \\
\hline In(Summers-Heston $K / L$ ) & & & & & $\begin{array}{c}-18.90^{* *} \\
(7.31)\end{array}$ \\
\hline Regional groupings & Yes & Yes & Yes & Yes & Yes \\
\hline $\begin{array}{l}\text { Latitude, religion dummies, legal } \\
\text { origin dummies, fractionalization index }\end{array}$ & & & Yes & Yes & Yes \\
\hline AIC & 353.80 & 349.90 & 358.40 & 197.90 & 223.50 \\
\hline $\mathrm{BIC}$ & 378.70 & 380.50 & 400.50 & 231.20 & 259.00 \\
\hline Adjusted $R^{2}$ & 0.54 & 0.59 & 0.54 & 0.62 & 0.59 \\
\hline Number of observations & 50 & 50 & 50 & 36 & 40 \\
\hline
\end{tabular}




\section{Bandyopadhyay and Roy}

remain significant at the conventional level (see column D of Tables 4 and 5). The difference in the results probably can be attributed to the differences in the methodology and the assumptions behind construction of the data on capital stock, as these different cross-country datasets return different country rankings on capital per worker. ${ }^{8}$

\section{CONCLUSION}

Using cross-country trade-protection data for non-agricultural commodities, we find that in the presence of inequality and left-wing ideology, corruption is systematically related to higher protection in labor-abundant countries and lower protection in capital-abundant countries, thereby

8 See Barseghyan and DiCecio (2010) for a discussion in this regard. hurting labor (i.e., the median voter) in both situations. Moreover, we find that in the presence of inequality and corruption, political ideology may not be a significant factor in explaining trade protection for non-agricultural goods. The hypothesis that left-leaning governments will be pro-labor in their trade policy is supported only in a small number of specifications. On the other hand, the inequality hypothesis receives more consistent support as a major determinant of nonagricultural trade policy. These differences in our findings relative to Dutt and Mitra (2002, 2005, and 2006) are interesting, and our use of nonagricultural trade-protection data seems to be critical. The results also bring to light the interactions among inequality, ideology, and corruption in determining trade policy. Future work in this area should take the influence of lobbying into consideration, in addition to invoking concerns about the majority rule and the partisan nature of government.

\section{REFERENCES}

Azfar, Omar. "The New Institutional Approach to Economic Development: An Analytic Primer.” Paper No. 02/03, IRIS Center, University of Maryland, March 2002; www.iris.umd.edu/Reader.aspx?TYPE=FORMAL PUBLICATION\&ID=70843195-11ce-426b-b8ff-bb0076128693.

Barro, Robert J. and Lee, Jong-Wha. "International Data on Educational Attainment: Updates and Implications.” Working Paper No. 42, Center for International Development, Harvard University, April 2000; www.hks.harvard.edu/centers/cid/publications/faculty-working-papers/cid-working-paper-no.-42.

Barseghyan, Levon and DiCecio, Riccardo. "Cross-country Income Convergence Revisited.” Working Paper No. 2010-021, Federal Reserve Bank of St. Louis, July 2010; http://research.stlouisfed.org/wp/2010/2010-021.pdf.

Beck, Thorsten; Clarke, George; Groff, Alberto; Keefer, Philip and Walsh, Patrick. "New Tools and New Tests in Comparative Political Economy: The Database of Political Institutions.” World Bank Economic Review, 2001, 15(1), pp. 165-76.

Coughlin, Cletus C. "Measuring International Trade Policy: A Primer on Trade Restrictiveness Indices.” Federal Reserve Bank of St. Louis Review, September/October 2010, 92(5), pp. 381-94; http://research.stlouisfed.org/publications/review/10/09/Coughlin.pdf.

Djerdjian, Daron O. “Ideology, Inequality and Inequitable Trade Policies.” B.E. Journal of Economic Analysis \& Policy, August 2007, 7(1), Article 39.

Dutt, Pushan and Mitra, Devashish. "Endogenous Trade Policy through Majority Voting: An Empirical Investigation.” Journal of International Economics, October 2002, 58(1), pp. 107-33. 
Dutt, Pushan and Mitra, Devashish. "Political Ideology and Endogenous Trade Policy: An Empirical Investigation." Review of Economics and Statistics, February 2005, 87(1), pp. 59-72.

Dutt, Pushan and Mitra, Devashish. "Labor versus Capital in Trade-Policy: The Role of Ideology and Inequality." Journal of International Economics, July 2006, 69(2), pp. 310-20.

Easterly, William. "Inequality Does Cause Underdevelopment: Insights from a New Instrument.” Journal of Development Economics, November 2007, 84(2), pp. 755-76.

Findlay, Ronald and Wellisz, Stanislaw. "Endogenous Tariffs, the Political Economy of Trade Restrictions, and Welfare,” in J. Bhagwati, ed., Import Competition and Response. Chicago: University of Chicago, 1982.

Gawande, Kishore; Krishna, Pravin and Olarreaga, Marcelo. "What Governments Maximize and Why: The View from Trade.” International Organization, Summer 2009, 63(3), pp. 491-532.

Grossman, Gene M. and Helpman, Elhanan. "Protection for Sale." American Economic Review, September 1994, 84(4), pp. 833-50.

Hillman, Arye L. "Declining Industries and Political Support Protectionist Motives." American Economic Review, December 1982, 72(5), pp. 1180-87.

Kaufmann, Daniel; Kraay, Aart and Mastruzzi, Massimo. "The Worldwide Governance Indicators: Methodology and Analytical Issues.” Policy Research Working Paper No. 5430, World Bank, 2010; http://siteresources.worldbank.org/INTMACRO/Resources/WPS5430.pdf.

Kee, Hiau Looi; Nicita, Alessandro and Olarreaga, Marcelo. "Estimating Trade Restrictiveness Indices." Economic Journal, January 2009, 119(534), pp. 172-99.

La Porta, Rafael; Lopez-de-Silanes, Florencio; Shleifer, Andrei and Vishny, Robert. "The Quality of Government." Journal of Law, Economics, and Organization, 1999, 15(1), pp. 222-79.

Milner, Helen V. and Kubota, Keiko. "Why the Move to Free Trade? Democracy and Trade Policy in the Developing Countries.” International Organization, Winter 2005, 59(1), pp. 107-43.

Murray, Michael P. “Avoiding Invalid Instruments and Coping with Weak Instruments.” Journal of Economic Perspectives, Fall 2006, 20(4), pp. 111-32.

Neeman, Zvika; Paserman, M. Daniele and Simhon, Avi. "Corruption and Openness." B.E. Journal of Economic Analysis \& Policy, 2008, 8(1), Article 50.

Nehru, Vikram and Dhareshwar, Ashok. "A New Database on Physical Capital Stock: Sources, Methodology, and Results.” Revista de Análisis Económico (Economic Analysis Review), 1993, 8(1), pp. 37-59.

Roy, Suryadipta. “Is Corruption Anti-labour?” Applied Economics Letters, March/April 2010, 17(4-6), pp. 329-33. 


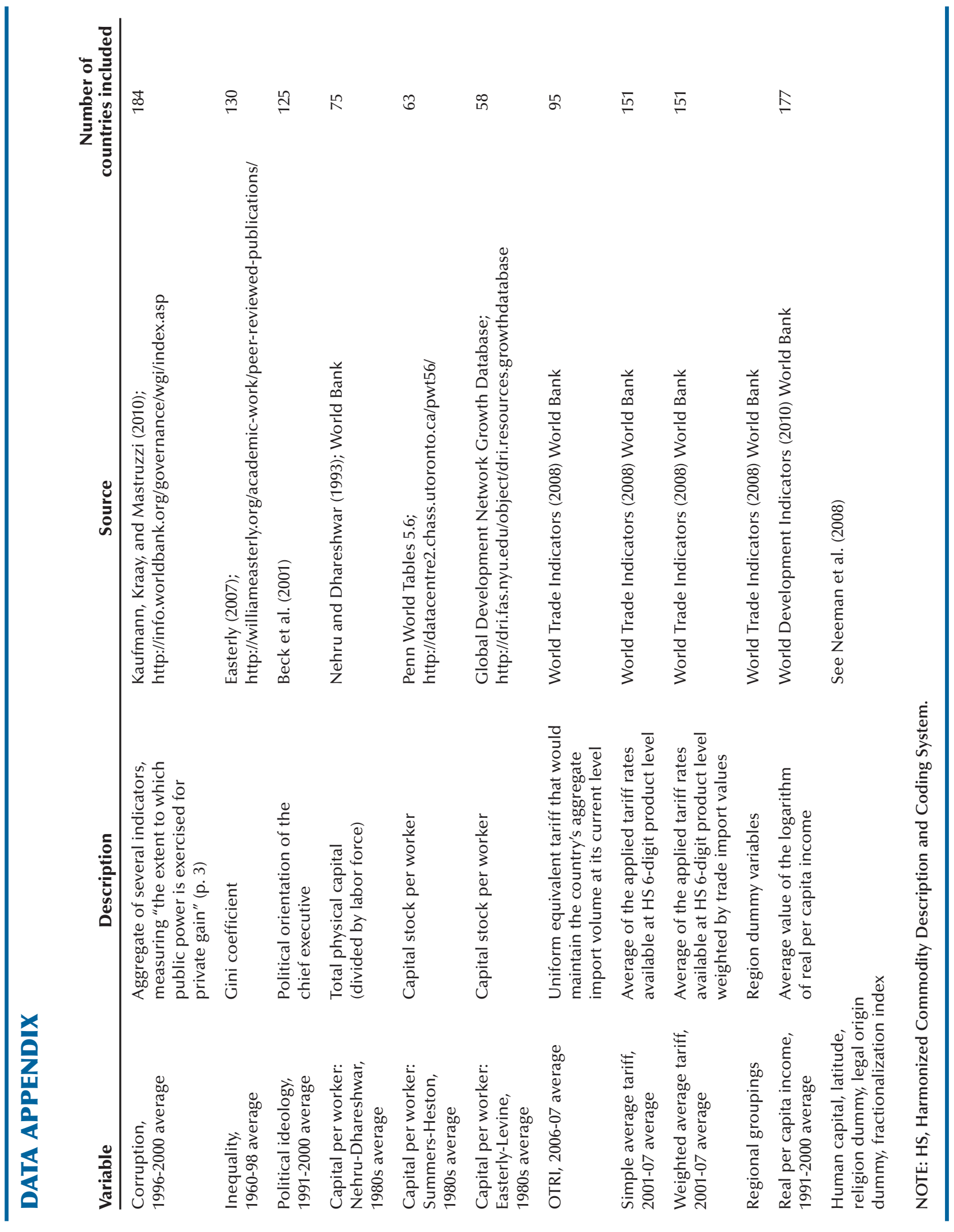

